\title{
A report on the international conference titled 1918 rik $w$ istorii Centralno-Schidnoj Jewropy: do 100-riczczia progołoszenija niezależnosti UNR ta 100-riczczia jeidorożenija polskoj dierżawnosti, Charków, September 27-29, 2018
}

September 27-29, 2018 at V.N. Karazin Kharkov
National University an international conference on the
occasion of the $100^{\text {th }}$ anniversary of independence of the Ukrainian People's Republic and the $100^{\text {th }}$ anniversary of rebirth of the Polish state took place. Its organisers were, besides the host of the conference, Polish and Ukrainian universities: O.M. Beketov National University of Urban Economy in Kharkov, Petro Mohyla Black Sea National University in Mykolayiv, Maria Curie Skłodowska University in Lublin and Nicolaus Copernicus University in Torun. The conference was financially supported by the Consulate General of Poland in Kharkov (which, among other things, covered costs of air travel and accommodation of some Polish participants) and the Canadian Institute of Ukrainian Studies of the University of Alberta. The languages of the conference were: Ukrainian, Polish, English and Russian. Tatiana Bitkowa, head of the Ukrainian-Polish Academic Centre of Science and Culture at V.N. Karazin Kharkov National University, was looking after Polish participants of the conference.

The rector of V.N. Karazin Kharkov National University, Wil Bakirow, the consul general of Poland in Kharkov, Janusz Jabłonski, and the director of the programme of modern Ukrainian studies at the Canadian Institute of Ukrainian Studies of the University of Alberta, Wołodymyr Kravchenko, opened the conference.

Later on, a short plenary session with synthetic presentations took place. First speech titled Ukraine: the legacy of 1918 was delivered by Władysław Wierstiuk from the Institute of Ukrainian History of the National Academy of Sciences of Ukraine in Kiev. Anatolij Rusnaczenko from V.I. Vernadsky Taurida National University in Kiev presented the 
topic Between two Empires: 1918 in the Baltic countries and Ukraine. The last paper titled The pro-Pitsudski's concept of a new balance of power in East Central Europe in 1918-1921 was delivered by Piotr Okulewicz from the University of Adam Mickiewicz in Poznan. After the discussion on the subject of interest of the above-mentioned speeches, the presentation of books and magazines that have appeared in recent years, the Polish ones included (e.g. the dictionary of eminent Poles in Kharkov), took place.

The conference was divided into three thematic sections. Each section was headed by two moderators (one from Ukraine, one from Poland) and a secretary. The first section titled Ukrainians and Poles during the World War I was led by Dmytro Czornyj from V.N. Karazin Kharkov National University and Mariusz Korzeniowski from Maria Curie Skłodowska University in Lublin. The section was dominated by papers on Ukrainians and Poles during the World War I and the revolution: Larysa Syniawska from Bohdan Khmelnytsky National University of Cherkasy Evacuation of enterprises during the World War I: planned deportations/plunder of the Polish industry, Wiktoria Węgierska from Zhytomyr Ivan Franko State University National troops during the World War I: similarities, differences and political effects of the activity, Olga Biłobrowiec from Zhytomyr Ivan Franko State University The attitude of Poles living in Ukraine to the creation of the national army during the World War I, Oleksander Kowalenko and Oleksander Rachno from Taras Shevchenko National University of Kyiv Formation of national military units and squads of Ukrainian Free Cossacks in the territory of the Chernihiv Governorate in 1917-1918, Walentyna Szewczenko from the Institute of Ukrainian History of the National Academy of Sciences of Ukraine in Kiev Transformation of the city government of Kharkov in the war-revolutionary period of 19141918, Mariusz Korzeniowski from Maria Curie Skłodowska University in Lublin Poles in Kiev and Ukrainian aspirations for independence in 1917-1918 and Tatiana Kowalenko from V.N. Karazin Kharkov National University Re-evacuation of Polish refugees in 1917-1918. Other papers presented during that section concerned cultural, political as well as economic history: Walentyna Nestorenko from the Cherkassy Regional Museum of Local Lore Karol Szymanowski in Jelizawietgrad (1917-1919), Olga Hajdaj from Petro Mohyla Black Sea National University in Mykolayiv Participation of representatives of the Polish Democrats in the Central Council and Natalia Trifonowa from the Museum of Money of the National Bank of Ukraine in Kiev The 
National Bank of Ukraine and the issue of first bonds of the Ukrainian People's Republic.

The second section titled Ukraine in 1918: the state-building processes was headed by Lubow Żwanko from O.M. Beketov National University of Urban Economy in Kharkov and Maciej Krotofil from Nicolaus Copernicus University in Torun. The first part of that section was dominated by papers on the history of Ukraine: Oleksandra Kudłaj from the Institute of Ukrainian History of the National Academy of Sciences of Ukraine in Kiev Diplomacy of the Ukrainian People's Republic and the treaty of Brest-Litovsk. The state of research in a contemporary Ukrainian historiography, Irina Szandra from the Kharkov State Academy of Culture Representative business organisations and Ukrainian offices in 1918: seeking ways of communication, Anna Kyrydon from the State Scientific Institution 'Reference Book' Year 1918: institutionalisation of the church life in Ukraine, Lubow Żwanko from O.M. Beketov National University of Urban Economy in Kharkov The Ukrainian State of Pawet Skoropadski: social aspects of internal politics (April-December 1918) and Walery Lewczenko from the Odessa National Maritime University The policy of the Ukrainian State in the field of higher education. Several papers concerned the history of Kharkov in 1918: Serhij Naumow from V.N. Karazin Kharkov National University The Kharkov University in 1918: 'ukrainisation', Dmytr Czorny from V.N. Karazin Kharkov National University Blind alleys of political pragmatism: the elite of the Kharkov Governorate in 1918, Serhij Dejnenko from M.F. Sumtsov Kharkov Historical Museum Main Kharkov customs chambers in Belgorod and Valuyki in the Ukrainian State (1918) and Wiaczesław Potocki from V.N. Karazin Kharkov National University Problems with law and order in the town of Kharkov after the overthrow of the hetman regime (December 1918). Subsequently, papers on military history were presented: Oleksandr Konik from the Kherson State University The last stage of the World War I: the 'human dimension' (in the light of documents of the Archives of the Kherson Oblast), Maria Rohoży from Pawel Tyczyna Pedagogical University in Uman The battle of Motowyliwka: place in the struggle of the national liberation, Maciej Krotofil from Nicolaus Copernicus University in Torun Military potential of Ukrainians in the second half of 1918: an attempt of an analysis and Mykoła Jacuk from O.M. Beketov National University of Urban Economy in Kharkov Organisation of military and political training by the Directorate of the Ukrainian People's Republic in the conditions of the Russian-Bolshevik aggression. The second section ended with 
a lecture by Agnieszka Sawicz from the University of Adam Mickiewicz in Poznan Talks on independence over Lviv coffee.

The third section titled Year 1918 as the breakthrough date of the latest history of East Central Europe was headed by Olena Bogdaszyna from H.S. Skovoroda Kharkov National Pedagogical University and Tadeusz Srogosz from Jan Długosz University in Częstochowa. Papers on various topics were discussed during that section. Some of them concerned beginnings of the statehood in Ukraine and Poland: Olga Morozowa from Petro Mohyla Black Sea National University in Mykolayiv Year 1918 - an important date in the history of Ukraine and Poland, Tadeusz Srogosz from Jan Długosz University in Częstochowa The participation of historians in Polish and Ukrainian central state authorities in the years 1917-1921, Tomasz Matuszak from the State Archives in Piotrków Trybunalski The rebirth of the statehood and the awareness of the society. Difficult beginnings of the state archival service of the Second Polish Republic and Oleksandr Sicz from Yuriy Fedkowych Chernivtsi National University Problems of civilizational choice in the countries of East Central Europe after the World War I. Some of the speakers presented issues related to the formation of borders and related conflicts: Serhij Hanus from the Uzhhorod National University Eastern Galicia in projects of the rebirth of the Polish statehood: from Brest to Compiègne (January-November 1918), Roman Tymoszenko from the Institute of Ukrainian History of the National Academy of Sciences of Ukraine in Kiev West Ukrainian population at the end of the World War in 1918: between Kiev and Vienna, Dariusz Tarasiuk from Maria Curie Skłodowska University in Lublin The Polish-Ukrainian dispute on the Chetm land and Podlasie in 1918, Ihor Rajkiwski from Vasyl Stefanyk Precarpathian National University Ukrainian and Polish socialists in the conditions of the break-up of Austria-Hungary and of the proclamation of the West Ukrainian People's Republic: between confrontation and agreement, Grzegorz Skrukwa from the University of Adam Mickiewicz in Poznan Western regions of Poland and Ukraine and their armies in 1918-1919: Greater Poland and Galicia, the Army of Greater Poland and the Ukrainian Galician Army. A comparative analysis and Marek Mikołajczyk from the University of Adam Mickiewicz in Poznan The Polish-Bolshevik War in the account of Major Charles de Gaulle. A description of everyday life was included in Olena Bogdaszyna's, H.S. Skovoroda Kharkov National Pedagogical University, and Dmytr Połupanow's, Kharkov Computer Technology College of National Technical University 
'Kharkov Polytechnic Institute', paper titled Between old and new: Russia at a crossroads (revolutionary Petrograd in the memories of M.D. Wrangel). As the Centre for Balkan Studies is active at V.N. Karazin Kharkov National University, papers on history of Bulgaria were also presented at the conference in question: Dmytr Mykolenko from V.N. Karazin Kharkov National University Bulgaria's defeat in 1918 in the opinion of the People's Liberal Party and Serhij Potraszkow from the Kharkov State Academy of Culture The "Red" terror in Russia and the execution of General Radko Dimitriew.

The meeting of the round table Ukrainian-Polish relations in the years 1918-1921: a history lesson and the legacy for the present was of a plenary character. This part of the conference was headed by Evgen Sinkiewicz from Petro Mohyla Black Sea National University in Mykolayiv and Mirosław Szumiło from the Institute of National Remembrance in Warsaw. Speeches concerning Polish-Ukrainian relations were delivered by: Serhiy Trojan from the National Aviation University in Kiev and Anna Kyrydon from the State Scientific Institution 'Reference Book' Ukrainian and Polish state projects after the World War I: problems of implementation in the light of the concept of Jan Stanisław Łoś, Mirosław Szumiła from the Institute of National Remembrance in Warsaw Was there a chance for a victory of the Polish-Ukrainian alliance in 1920?, Evgen Sinkiewicz from Petro Mohyla Black Sea National University in Mykolayiv The fate of 'Petlura's followers' in the territories of the Second Polish Republic in the light of historiography, Marina Czyrkowa from the Poltava M.V. Ostrogradsky Regional Institute of Postgraduate Pedagogical Education Peculiarities of repatriates of Polish subjects of the Russian Empire from the Ukrainian Soviet Socialist Republic in the years 1921-1923 (on the example of the Poltava region) and Olga Rabczenko from H.S. Skovoroda Kharkov National Pedagogical University The 'boycott' of Polish higher education institutions for young people in Ukraine: causes and consequences (1920-1925).

At the end of the conference, the last section as well as the entire conference were summarised.

TADEUSZ SROGOSZ Jan Dlugosz University in CZęstochowa*

\footnotetext{
* Faculty of Philosophy and History, Institute of History, Department of Methodology of History and History of Historiography / Wydział Filologiczno-Historyczny, Instytut Historii, Zakład Metodologii Historii i Historii Historiografii, e-mail: tadeusz.srogosz@ajd.czest.pl.
} 